\title{
Varietas Non Hibrida Cabai Besar Anies IPB
}

\author{
Non Hybrid Variety of Big Pepper Anies IPB
}

\author{
Muhamad Syukur ${ }^{1,2^{*}}$, Sobir ${ }^{1,2}$, Siti Marwiyah ${ }^{1,2}$, Awang Maharijaya ${ }^{1,2}$, Anas D. Susila ${ }^{1,2}$, \\ Darda Efendi ${ }^{1,2}$, Widodo ${ }^{1,3}$, Sri Hendrastuti Hidayat ${ }^{1,3}$, Vitria P. Rahadi ${ }^{1}$, \\ Abdul Hakim ${ }^{1}$, Tiara Yudilastari ${ }^{1}$, Arya Widura Ritonga ${ }^{1}{ }^{1,}$, Ilham Framansyah ${ }^{1}$
}

\author{
'Pusat Kajian Hortikultura Tropika, LPPM IPB, \\ Jl. Raya Pajajaran Baranangsiang, Bogor, Indonesia \\ ${ }^{2}$ Departemen Agronomi dan Hortikutura, Fakultas Pertanian IPB, \\ Jl. Meranti Kampus IPB Dramaga, Bogor 16680, Indonesia \\ ${ }^{3}$ Departemen Proteksi Tanaman, Fakultas Pertanian IPB, \\ Jl. Meranti Kampus IPB Dramaga, Bogor 16680, Indonesia \\ *Penulis untuk korespondensi: muhsyukur@ipb.ac.id
}

Diterima 20 November 2016/Disetujui 9 Januari 2017

\begin{abstract}
The pepper is very important horticultural commodities. The purpose of this research was to study the advantages of Anies IPB varieties and develop the description. Anies IPB was the result of the selection of segregating populations from the crosses of IPB C120 (as the female parent) and IPB C5 (as the male parent). The experiments were performed in four locations namely Boyolali (Central Java), Sumedang (West Java), and Bogor (West Java). The experimental used the randomized complete block design (RCBD) two factors with three replications. The replications nested within the locations. The first factor was 9 lines and 2 open pollinated varieties, and the second factor was the three locations. Each lines on each replicate in each location were planted 24 plants. The results showed that the superiority of Anies IPB varieties were (1) The productivity of Anies IPB was higher than the check varieties. Productivity can reach 18.6 tons ha ${ }^{-1}$. (2) Anies IPB has fruit that was longer than the Tit Super and Trisula. (3) Anies IPB has early-harvesting time, ranged between $76.67-84.67$ days after planting. (4) Anies IPB has a high level of stability and classified into the dynamic stability, which means that very adaptive to the optimum environment.
\end{abstract}

Keyword: non hybrid, pepper productivity superiority, variety

\section{ABSTRAK}

Cabai merupakan salah satu komoditas hortikultura yang sangat penting. Tujuan penelitian ini adalah untukmempelajari keunggulan varietas Anies IPB dan menyusun deskripsinya. Anies IPB merupakan hasil seleksi populasi bersegregasi dari persilangan IPB C120 (sebagai tetua betina) dan IPB C5 (sebagai tetua jantan). Percobaan dilakukan di empat lokasi yaitu Boyolali (Jawa Tengah), Sumedang (Jawa Barat), dan Bogor (Jawa Barat). Percobaan menggunakan Rancangan Kelompok Lengkap Teracak Kelompok (RKLT) dua faktor dengan 3 ulangan. Ulangan tersarang dalam lokasi. Faktor pertama adalah 9 galur cabai bersari bebas dan 2 varietas pembanding, faktor kedua adalah tiga lokasi. Setiap galur pada masing-masing ulangan di masing-masing lokasi ditanam 24 tanaman. Hasil penelitian menunjukkan bahwa keunggulan varietas Anies IPB adalah (1) produktivitas Anies IPB lebih tinggi dibandingkan dengan varietas pembanding. Produktivitasnya dapat mencapai 18.6 ton ha-1. (2) Anies IPB mempunyai buah yang lebih panjang dari pada Tit Super dan Trisula. (3) Anies IPB memiliki umur panen yang genjah yaitu berkisar antara 76.67 - 84.67 hari setelah tanam. (4) Anies IPB mempunyai tingkat stabilitas tinggi dan digolongkan ke dalam stabilitas dinamis, artinya sangat adaptif terhadap lingkungan optimum.

Kata kunci: cabai, keunggulan, non hibrida, produktivitas, varietas

\section{PENDAHULUAN}

Cabai (Capsicum annuum L.) merupakan salah satu komoditas hortikultura utama di Indonesia. Hal ini dibuktikan dengan luas pertanaman cabai yang mencapai 254 ribu hektar menjadi luasan komoditas sayuran terbesar di Indonesia (Direktorat Jenderal Hortikultura, 2016). Selain itu, cabai sering kali menjadi penyumbang kenaikan inflasi paling utama pada kelompok volatile food di Indonesia seperti pada bulan September dan Oktober 2016 (Bank Indonesia, 2016). 
Produktivitas cabai di Indonesia terus meningkat sejak 2010, namun demikian tingkat produktivitasnya baru mencapai 8.35 ton ha $^{-1}$ untuk cabai besar dan 5.94 ton ha ${ }^{-1}$ untuk cabai rawit (Direktorat Jenderal Hortikultura, 2016). Hal ini masih jauh dibandingkan potensinya yang dapat mencapai 20 ton ha $^{-1}$ (Syukur et al., 2010). Oleh karena itu perlu terus dilakukan perbaikan genetik maupun sistem budi daya cabai agar produktivitas cabai di Indonesia optimal.

Sejak tahun 1994 s.d. 2012 telah banyak dilakukan penelitian dan pengembangan varietas unggul cabai. Sebanyak 204 varietas telah dilepas oleh Menteri Pertanian tetapi belum dapat mencukupi kebutuhan cabai karena kebutuhan cabai semakin meningkat setiap tahunnya. Pengembangan dan perakitan varietas unggul cabai terus diupayakan untuk mengatasi masalah tersebut. Varietas unggul yang diharapkan adalah varietas yang memiliki produktivitas tinggi, tahan terhadap serangan hama dan penyakit, serta mampu tumbuh sesuai dengan lingkungan tumbuhnya atau agroekologi. Sebagian besar varietas unggul yang dilepas adalah hasil introduksi dari luar negeri dan hibrida (Syukur et al., 2015). Oleh karena itu pendaftaran varietas cabai bersari bebas ini dilakukan.

Program perakitan cabai bersari bebas sudah dilakukan di Bagian Genetika dan Pemuliaan Tanaman Departemen Agronomi dan Hortikultura dan Pusat Kajian Hortikultura Tropika (PKHT) sejak tahun 2003. Saat ini telah diperoleh beberapa galur yang mempunyai potensi hasil tinggi. Galurgalur tersebut perlu diuji keunggulannya di beberapa lokasi dalam rangka memenuhi syarat untuk pendaftaran varietas komersial di Komenterian Pertanian. Penulisan artikel ini bertujuan untuk mempelajari keunggulan varietas Anies IPB, menyusun deskripsinya hingga diperoleh SK pendaftaran varietas komersial dari Kementerian Pertanian.

\section{SILSILAH VARIETAS}

Anies IPB merupakan hasil seleksi populasi bersegregasi dari persilangan IPB C120 (sebagai tetua betina) dan IPB C5 (sebagai tetua jantan) (Tabel 1). Seleksi bulk dimodifikasi dimulai pada populasi F5, dilanjutkan

Tabel 1. Deskripsi tetua betina dan tetua jantan

\begin{tabular}{|c|c|c|c|}
\hline No. & Karakter & Tetua Betina (IPB C120) & Tetua Jantan (IPB C5) \\
\hline 1. & Warna batang & Hijau & Hijau dengan garis ungu \\
\hline 2. & Warna buku batang & Ungu & Ungu \\
\hline 3. & Bentuk batang & Bulat & Flattened \\
\hline 4. & Habitus tanaman & Intermediate & Intermediate \\
\hline 5. & Warna daun & Hijau & Hijau \\
\hline 6. & Bentuk daun & Lanset & Lanset \\
\hline \multirow[t]{2}{*}{7.} & Posisi bunga & Semi jatuh & Sedang/ \\
\hline & & & intermediate \\
\hline 8. & Warna mahkota bunga & Putih & Putih \\
\hline 9. & Warna anter & Ungu & Ungu \\
\hline 10. & Pinggiran mahkota & Tidak bergerigi & Tidak bergerigi \\
\hline 11. & Penampang melintang buah & Circular & Agak bergelombang \\
\hline 12. & Warna buah intermediate & Hijau gelap & Oranye \\
\hline 13. & Warna buah masak & Merah & Merah \\
\hline 14. & Permukaan buah & Berkerut & Halus \\
\hline 15. & Bentuk buah & Memanjang & Kerucut \\
\hline 16. & Tinggi dikotomus $(\mathrm{cm})$ & 33.72 & 20.81 \\
\hline 17. & Lebar kanopi $(\mathrm{cm})$ & 134 & 71.67 \\
\hline 18. & Umur Berbunga (HST) & 25 & 33 \\
\hline 19. & Umur panen (HST) & 73.75 & 95 \\
\hline 20. & Bobot buah (g) & 5.07 & 17.89 \\
\hline 21. & Panjang buah $(\mathrm{cm})$ & 22.09 & 10.67 \\
\hline 22. & Diameter buah (mm) & 0.76 & 2.38 \\
\hline 23. & Bobot buah total per tanaman $(\mathrm{g})$ & 484.23 & 695.6 \\
\hline 24. & Hasil per hektar (ton) & 11.6 & 16.67 \\
\hline 25. & Instansi Pemulia & Fakultas Pertanian IPB & Fakultas Pertanian IPB \\
\hline
\end{tabular}


ke F6 hingga F7. Uji daya hasil pendahuluan dan lanjutan dilakukan pada populasi F8 (Gambar 1).

Perakitan varietas cabai Anies IPB diarahkan kepada peningkatan produktivitas dan kualitas buah. Varietas Anies IPB adalah varietas non hibrida. Tetua betina yang digunakan adalah IPB C120 (cabai keriting koleksi Bagian Genetika dan Pemuliaan Tanaman, Departemen Agronomi dan Hortikultura IPB asal Sumatera Barat), merupakan donor jumlah buah buah banyak, ukuran buah panjang (rata-rata $20 \mathrm{~cm}$ ) namun bobot buah tidak terlalu besar. Tetua jantan adalah IPB C5 (cabai besar koleksi Bagian Genetika dan Pemuliaan Tanaman, Depertemen Agronomi dan Hortikultura IPB), merupakan donor diameter besar dan permukaan kulit licin.

Cabai adalah termasuk tanaman menyerbuk sendiri yang diperbanyak melalui benih, namun demikian persentase menyerbuk silang cukup tinggi yaitu dapat mencapai 35\%. Oleh karena itu varietas cabai yang dihasilkan dapat berupa cabai hibrida maupun non hibrida. Dengan demikian perakitan varietas cabai dapat mengikuti alur perakitan varietas hibrida untuk menghasilkan varietas hibrida dan alur perakitan varietas galur murni (dimodifikasi) untuk menghasilkan varietas non hibrida (Syukur et al., 2015).

Berdasarkan tipe perkembangbiakan tanaman tersebut maka metode pemuliaan tanaman cabai diantaranya adalah Bulk, Pedigree, SSD, Silang Balik, Seleksi Massa, dan Seleksi Galur Murni. Perakitan varietas Anies IPB menggunakan Metode Pemuliaan Pedigree.Persilangan antara IPB C120 x IPB C5 menghasilkan F1. Benih F1 diselfing menghasilkan F2. Seleksi mulai dilakukan pada tanaman F2. Setiap nomor pada setiap generasi hasil seleksi

F1

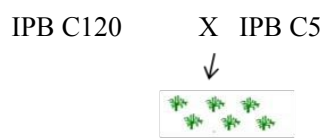

F2

F3
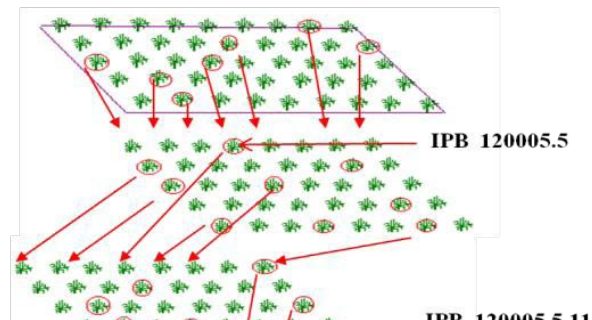

F4

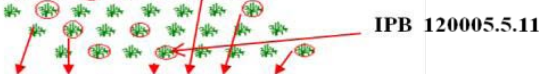

F5

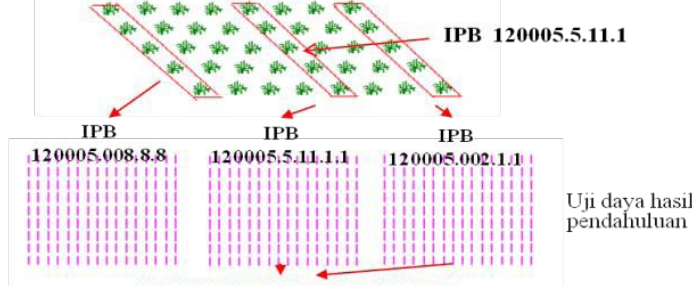

F6

F7

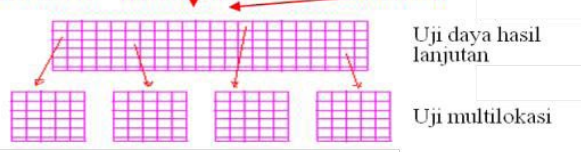

Gambar 1. Metode Pemuliaan Modifikasi Bulk untuk Perakitan Varietas Cabai Anies IPB dicatat dengan baik. Hasil seleksi F2 (berupa benih F3) ditanam menjadi tanaman F3.Seleksi dilakukan terhadap famili terbaik, yang dilanjutkan dengan seleksi individu terbaik (seleksi individu dalam famili). Seleksi pada F4 masih sama dengan F3. Pada F5 seleksi dilakukan pada galur-galur (famili) terbaik.Galur-galur F6 dilakukan seleksi untuk uji daya hasil pendahuluan.Hasil seleksi F6 berupa galur IPB 120005.008.8.8, IPB 120005.005.5.4, IPB 120005.002.1.1.dan IPB 120005.5.11.1.1. Hasil uji daya hasil pendahuluan menghasilkan IPB 120005.5.11.1 untuk uji multilokasi dalam rangka pendaftaran varietas tanaman. Pedigree Anies IPB 120005.5.11.1.1 diberi nama Anies IPB.

\section{BAHAN DAN METODE}

Bahan yang digunakan dalam percobaan ini terdiri atas 9 galur cabai IPB yaitu Anies IPB, IPB002001, IPB002046, IPB009003, IPB009019, IPB015002, IPB015008serta dua varietas pembanding. Varietas pembanding adalah Tit Super dan Trisula.

Percobaan mulai pada bulan Januari 2010 sampai dengan Agustus 2011. Percobaan dilakukan di empat lokasi yaitu Boyolali (Jawa Tengah), Sumedang (Jawa Barat), dan Bogor (Jawa Barat).

Rancangan percobaan yang digunakan dalam penelitian ini adalah Rancangan Kelompok Lengkap Teracak Kelompok (RKLT) dua faktor dengan 3 ulangan. Ulangan tersarang dalam lokasi. Faktor pertama adalah 9 galur cabai bersari bebas dan 2 varietas pembanding, faktor kedua adalah tiga lokasi. Setiap galur pada masing-masing ulangan di masing-masing lokasi ditanam 24 tanaman.

Benih cabai disemaikan dahulu pada tray semai yang berisi media tanam steril. Pada umur kurang lebih lima minggu selama persemaian atau bibit sudah mempunyai 3-4 helai daun, tanaman siap untuk dipindahkan ke lapang. Pengolahan lahan dilakukan dua minggu sebelum pindah tanam yaitu dengan menggemburkan tanah dan mengaplikasikan pupuk kandang $1 \mathrm{~kg} / \mathrm{lubang}$, dengan ukuran bedeng 1 x $10 \mathrm{~m}$ dan jarak tanam 0.5 x $0.5 \mathrm{~m}$. Pupuk dasar Urea 200 kg/ha, SP-36 150 kg/ha dan KCl 150 kg/ha diberikan pada 5 hari sebelum tanam. Setelah itu bedengan ditutup dengan mulsa plastik hitam perak.

Pemeliharaan tanaman cabai meliputi penyiraman, pengajiran, penyiangan, pewiwilan, pengendalian hama penyakit tanaman, dan pemupukan susulan. Pengajiran dilakukan untuk menopang tanaman saat berbuah lebat. Pengajiran dilakukan 3 hari setelah tanam. Ajir terbuat dari bambu dengan panjang $120 \mathrm{~cm}$, ditancapkan 10 cm dari pohon, ditanam dalam tanah sedalam 20-30 cm dengan posisi miring keluar. Pengikatan tanaman pada ajir dilakukan pada umur 2 MST dengan tali rafia. Penyiangan dilakukan secara manual dua minggu sekali atau sesuai pertumbuhan gulma. Pengendalian hama dan penyakit tanaman dilakukan tiap minggu, yaitu bila terlihat adanya gejala serangan hama dan atau penyakit. Tindakan preventif dilakukan penyemprotan pestisida setiap minggu setelah tanam dengan insektisida atau fungisida secara bergantian, 
dengan dosis sesuai anjuran. Pestisida yang digunakan pada percobaan ini adalah Curacron, Kelthane, Anthracol, Dithane dan Prostiker sebagai perekat. Pemberian pupuk susulan dilakukan pada tiap minggu dengan NPK Mutiara 16-16-16 dengan dosis $10 \mathrm{~g} /$ liter. Cara pemberiannya adalah dengan menyiramkan larutan pupuk $250 \mathrm{ml}$ per tanaman.

Peubah yang diamati adalah umur panen (HST), panjang buah $(\mathrm{cm})$, diameter buah $(\mathrm{mm})$, tebal daging buah $(\mathrm{mm})$, bobot buah $(\mathrm{g})$, bobot buah per tanaman $(\mathrm{g})$. Jika nilai F-hitung berbeda nyata pada taraf 5\% maka dilanjutkan dengan uji DMRT 5\%. Pengujian tersebut menggunakan fasilitas SAS 9. Untuk mengetahui stabilitas hasil pada populasi cabai non hibrida dilakukan analisis stabilitas. Analisis stabilitas dilakukan dengan menggunakan metode analisis Additive Main Effect Multiplicative Interaction (AMMI).

\section{HASIL DAN PEMBAHASAN}

\section{Analisis Ragam Gabungan}

Analisis ragam gabungan dilakukan untuk mengetahui pengaruh genotipe, lokasi, musim dan interaksi ketiganya terhadap variabel yang diamati. Penanaman dilakukan di tiga lokasi yaitu Bogor (Jawa Barat), Sumedang (Jawa Barat), dan Boyolali (Jawa Timur). Penanaman dilakukan pada dua musim yaitu pada bulan Januari-Juni 2010 (musim 1) dan Maret - Agustus 2011 (Akhir musim hujan/musim 2). Hasil analisis menunjukkan bahwa genotipe berpengaruh nyata terhadap variabel yang diamati. Musim berpengaruh nyata pada sebagian variabel pengamatan kecuali tebal daging buah. Hasil analisis ini menunjukkan bahwa sebagian besar karakteristik galur yang diuji dipengaruhi oleh genotipe dan lokasi penanaman. Genotipe dan lokasi berinteraksi nyata pada setiap peubah yang diamati. Hasil analisis interaksi yang bernilai nyata pada peubah pengamatan menunjukkan bahwa karakteristik tanaman dipengaruhi juga oleh adanya interaksi antar faktor (Tabel 2).

\section{Umur Panen}

Pada musim 1 (Januari-Juni 2010), Anies IPB yang ditanam di Bogor memiliki umur panen yang lebih panjang dari pada varietas Tit Super dan Trisula sedangkan di daerah Sumedang dan Boyolali Anies IPB memiliki umur panen yang tidak berbeda nyata dengan Varietas Tit Super dan Trisula. Nilai rata-rata umur panen di ketiga tempat tersebut pada musim 1 menunjukkan bahwa Anies IPB memiliki umur panen yang lebih panjang dibanding varietas Trisula (Tabel 3).

Pada Musim 2 (Maret-Agustus 2010), Anies IPB yang ditanam di Bogor memiliki umur panen yang lebih panjang dari varietas Trisula. Anies IPB yang ditanam di Sumedang memiliki umur panen yang sama dengan semua genotipe lain dan varietas pembanding (Tit Super dan Trisula) sedangkan di Boyolali, Anies IPB memiliki umur panen yang lebih pendek dibanding varietas Trisula (Tabel 3). Syukur et al. (2015) menyatakan bahwa cabai yang dipanen lebih cepat akan menguntungkan petani. Oleh karena itu salah satu sasaran pemuliaan cabai adalah mendapatkan cabai yang berumur genjah.

\section{Panjang Buah}

Pada musim 1, Anies IPB memiliki buah yang lebih panjang dibanding dengan varietas Tit Super dan Trisula di lokasi penanaman Sumedang dan Boyolali sedangkan di Bogor panjang buah Anies IPB tidak berbeda nyata dengan varietas pembanding. Pada musim 2 Anies IPB memiliki buah yang lebih panjang dibanding dengan varietas pembanding di lokasi penanaman Bogor dan Sumedang, sedangkan di Boyolali panjang buah Anies IPB tidak berbeda nyata dengan varietas pembanding. Panjang buah Anies IPB berkisar antara $12.02-19.35 \mathrm{~cm}$ dengan rata-rata pada musim 1 dan musim 2 berturut-turut adalah $16.75 \mathrm{~cm}$ dan $13.92 \mathrm{~cm}$ (Tabel 4). Menurut Badan Standarisasi Nasional (1998), cabai besar termasuk ke dalam kriteria mutu I jika

Tabel 2. Analisis ragam gabungan karakter vegetatif 9 genotipe cabai pada tiga lokasi dan dua musim

\begin{tabular}{|c|c|c|c|c|c|c|c|}
\hline $\begin{array}{l}\text { Sumber } \\
\text { Keragaman }\end{array}$ & Umur Panen & B. Buah & P. Buah & D. Buah & TD Buah & BB Tanman & $\begin{array}{c}\text { Prod. } \\
\text { tanaman }\end{array}$ \\
\hline Musim (M) & $9.20 *$ & $195.19 * *$ & $227.82 * *$ & $58.69^{* *}$ & $3.39 \mathrm{tn}$ & $3.52 \mathrm{tn}$ & $3.52 \mathrm{tn}$ \\
\hline Lokasi (L) & $441.82 * *$ & $21.62 * *$ & $53.17 * *$ & $284.46^{* *}$ & $34.77 * *$ & $70.84 * *$ & $70.85 * *$ \\
\hline $\mathrm{M}^{*} \mathrm{~L}$ & $2.90 \mathrm{tn}$ & $31.44 * *$ & $62.86 * *$ & $19.76 * *$ & $8.95 * *$ & $23.15 * *$ & $23.14 * *$ \\
\hline Ulangan/M*L & $0.92 \mathrm{tn}$ & $0.78 \mathrm{tn}$ & $0.63 \mathrm{tn}$ & $0.81 \mathrm{tn}$ & $1.92 *$ & $3.21 * *$ & $3.21 * *$ \\
\hline Genotipe (G) & $15.78 * *$ & $29.35 * *$ & $51.73 * *$ & $88.12 * *$ & $9.06 * *$ & $3.09 * *$ & $3.09 * *$ \\
\hline $\mathrm{G}^{*} \mathrm{~L}$ & $11.79 * *$ & $4.23 * *$ & $9.44 * *$ & $14.11 * *$ & $2.53 *$ & $2.29 *$ & $2.29 *$ \\
\hline $\mathrm{G}^{*} \mathrm{M}$ & $17.35 * *$ & $9.88 * *$ & $15.03 * *$ & $11.08 * *$ & $4.95 * *$ & $3.65^{* *}$ & $3.65 * *$ \\
\hline $\mathrm{G}^{*} \mathrm{~L} * \mathrm{M}$ & $10.01 * *$ & $6.54 * *$ & $8.17 * *$ & $13.62 * *$ & $7.73 * *$ & $3.62 * *$ & $3.62 * *$ \\
\hline
\end{tabular}

Keterangan: $\left.{ }^{* *}\right)$ = berbeda nyata pada taraf $\left.0.01 ; *\right)$ berbeda nyata pada taraf $\left.0.05 ; \mathrm{tn}\right)=$ tidak berbeda nyata; $\mathrm{B}$. Buah $=$ Bobot buah; $\mathrm{P}$. Buah $=$ Panjang buah; $\quad$ D. Buah $=$ Diameter buah; TD Buah $=$ Tebal daging buah; BB Tanaman $=$ Bobot buah per tanaman; Prod. Tanaman $=$ Produktivitas tanaman 
Tabel 3. Nilai rata-rata umur panen (HST) di tiga lokasi dan dua musim

\begin{tabular}{llllllll}
\hline \multirow{2}{*}{ Genotipe } & \multicolumn{2}{c}{ Bogor } & \multicolumn{2}{c}{ Sumedang } & \multicolumn{2}{c}{ Boyolali } & \multirow{2}{*}{ Rataan } \\
\cline { 2 - 6 } & Musim 1 & Musim 2 & Musim 1 & Musim 2 & Musim 1 & Musim 2 & \\
\hline Anies IPB & $81.00 \mathrm{ab}$ & $76.67 \mathrm{ab}$ & $79.00 \mathrm{a}$ & $81.67 \mathrm{a}$ & $84.67 \mathrm{~b}$ & $80.67 \mathrm{~b}$ & $80.61 \mathrm{bc}$ \\
IPB002001 & $75.67 \mathrm{~b}$ & $72.00 \mathrm{abc}$ & $80.67 \mathrm{a}$ & $78.67 \mathrm{a}$ & $95.00 \mathrm{a}$ & $100.00 \mathrm{a}$ & $83.67 \mathrm{ab}$ \\
IPB002046 & $85.67 \mathrm{a}$ & $73.00 \mathrm{abc}$ & $77.33 \mathrm{a}$ & $82.67 \mathrm{a}$ & $96.67 \mathrm{a}$ & $83.00 \mathrm{~b}$ & $83.06 \mathrm{ab}$ \\
IPB009003 & $80.00 \mathrm{ab}$ & $79.67 \mathrm{a}$ & $81.00 \mathrm{a}$ & $83.00 \mathrm{a}$ & $93.33 \mathrm{ab}$ & $93.33 \mathrm{a}$ & $85.06 \mathrm{a}$ \\
IPB009019 & $80.33 \mathrm{ab}$ & $72.00 \mathrm{abc}$ & $82.00 \mathrm{a}$ & $81.33 \mathrm{a}$ & $96.00 \mathrm{a}$ & $95.00 \mathrm{a}$ & $84.44 \mathrm{a}$ \\
IPB015002 & $85.67 \mathrm{a}$ & $69.00 \mathrm{bc}$ & $80.33 \mathrm{a}$ & $79.67 \mathrm{a}$ & $92.00 \mathrm{ab}$ & $93.33 \mathrm{a}$ & $83.33 \mathrm{ab}$ \\
IPB015008 & $88.67 \mathrm{a}$ & $75.00 \mathrm{ab}$ & $82.00 \mathrm{a}$ & $81.67 \mathrm{a}$ & $95.67 \mathrm{a}$ & $93.33 \mathrm{a}$ & $86.06 \mathrm{a}$ \\
TIT Super & $59.67 \mathrm{c}$ & $64.33 \mathrm{c}$ & $81.00 \mathrm{a}$ & $77.67 \mathrm{a}$ & $92.67 \mathrm{ab}$ & $84.00 \mathrm{~b}$ & $76.56 \mathrm{~d}$ \\
Trisula & $43.33 \mathrm{~d}$ & $72.00 \mathrm{abc}$ & $83.67 \mathrm{a}$ & $81.00 \mathrm{a}$ & $92.00 \mathrm{ab}$ & $100.00 \mathrm{a}$ & $78.67 \mathrm{~cd}$ \\
\hline
\end{tabular}

Keterangan: Angka yang diikuti oleh huruf yang sama pada kolom yang sama tidak berbeda nyata berdasarkan uji BNJ pada taraf 5\%

Tabel 4. Nilai rata-rata panjang buah $(\mathrm{cm})$ di tiga lokasi dan dua musim

\begin{tabular}{llllllll}
\hline \multirow{2}{*}{ Genotipe } & \multicolumn{2}{c}{ Bogor } & \multicolumn{2}{c}{ Sumedang } & \multicolumn{2}{c}{ Boyolali } & \multirow{2}{*}{ Rataan } \\
\cline { 2 - 6 } & Musim 1 & Musim 2 & Musim 1 & Musim 2 & Musim 1 & Musim 2 & \\
\hline Anies IPB & $14.57 \mathrm{ab}$ & $14.81 \mathrm{c}$ & $19.35 \mathrm{a}$ & $14.94 \mathrm{a}$ & $16.34 \mathrm{a}$ & $12.02 \mathrm{abc}$ & $15.34 \mathrm{a}$ \\
IPB002001 & $12.93 \mathrm{bc}$ & $11.87 \mathrm{de}$ & $14.59 \mathrm{~b}$ & $11.10 \mathrm{~cd}$ & $11.08 \mathrm{~d}$ & $11.14 \mathrm{abc}$ & $12.12 \mathrm{de}$ \\
IPB002046 & $15.56 \mathrm{a}$ & $17.89 \mathrm{a}$ & $14.60 \mathrm{~b}$ & $13.49 \mathrm{ab}$ & $13.27 \mathrm{bc}$ & $13.12 \mathrm{a}$ & $14.65 \mathrm{ab}$ \\
IPB009003 & $12.02 \mathrm{c}$ & $10.85 \mathrm{e}$ & $11.10 \mathrm{~d}$ & $10.28 \mathrm{~d}$ & $14.67 \mathrm{ab}$ & $10.59 \mathrm{bc}$ & $11.59 \mathrm{e}$ \\
IPB009019 & $14.99 \mathrm{a}$ & $17.07 \mathrm{ab}$ & $12.49 \mathrm{~cd}$ & $12.63 \mathrm{bc}$ & $13.46 \mathrm{bc}$ & $11.90 \mathrm{abc}$ & $13.76 \mathrm{c}$ \\
IPB015002 & $12.51 \mathrm{c}$ & $12.20 \mathrm{de}$ & $15.90 \mathrm{~b}$ & $10.00 \mathrm{~d}$ & $12.49 \mathrm{~cd}$ & $11.78 \mathrm{abc}$ & $12.48 \mathrm{~d}$ \\
IPB015008 & $11.67 \mathrm{c}$ & $10.86 \mathrm{e}$ & $12.34 \mathrm{~cd}$ & $12.74 \mathrm{bc}$ & $14.47 \mathrm{abc}$ & $10.50 \mathrm{bc}$ & $12.10 \mathrm{de}$ \\
TIT Super & $13.59 \mathrm{abc}$ & $13.16 \mathrm{~cd}$ & $13.98 \mathrm{bc}$ & $11.76 \mathrm{bcd}$ & $14.02 \mathrm{bc}$ & $10.09 \mathrm{c}$ & $12.77 \mathrm{~d}$ \\
Trisula & $15.36 \mathrm{a}$ & $15.12 \mathrm{bc}$ & $15.58 \mathrm{~b}$ & $12.62 \mathrm{bc}$ & $12.56 \mathrm{~cd}$ & $12.27 \mathrm{ab}$ & $13.92 \mathrm{bc}$ \\
\hline
\end{tabular}

Keterangan: Angka yang diikuti oleh huruf yang sama pada kolom yang sama tidak berbeda nyata berdasarkan uji BNJ pada taraf 5\%

mempunyai panjang $12-14 \mathrm{~cm}$, mutu II dengan panjang 9 $11 \mathrm{~cm}$ dan mutu III dengan panjang $<9 \mathrm{~cm}$. Menurut Sayaka et al. (2008), salah satu industri yang berbahan baku cabai di Indonesia mensyaratkan kualitas cabai dengan ukuran panjang $9.5-14.5 \mathrm{~cm}$.

\section{Diameter Buah}

Di Boyolali Anies IPB memiliki diameter buah yang lebih besar dibanding varietas Trisula pada musim 1 . Dari hasil rata-rata nilai diameter buah dari setiap lokasi penanaman dan dua musim menunjukkan bahwa Anies IPB memiliki nilai diameter batang yang sama dengan varietas Trisula dan lebih kecil dari varietas Tit Super. Di Bogor, diameter Anies IPB lebih besar dari varietas Trisula dan sama dengan varetas Tit Super pada musim 2. Diameter buah Anies IPB berkisar antara 16.03-18.50 mm dengan rata-rata pada musim 1, musim 2 dan total berturut-turut adalah 17.69 mm, $16.58 \mathrm{~mm}$, dan $17.14 \mathrm{~mm}$ (Tabel 5). Penelitian yang dilakukan Hartuti dan Asgar (1992) mengungkapkan bahwa ada kriteria tertentu yang dikehendaki oleh industri dalam memperoleh bahan baku cabai olahan. Kriteria tersebut di antaranya adalah diameter cabai $1.0-1.5 \mathrm{~cm}$.

\section{Bobot Buah}

Bobot buah Anies IPB tidak berbeda nyata dengan varietas pembanding di setiap tempat penanaman dan pada dua musim. Bobot buah Anies IPB berkisar antara 10.31$14.00 \mathrm{~g}$, dengan rata-rata pada musim 1 , musim 2 dan rataan total berturut-turut sebesar $11.73 \mathrm{~g}, 10.71 \mathrm{~g}$, dan $11.22 \mathrm{~g}$. Bobot buah Anies IPB tertinggi terjadi pada daerah Boyolali pada musim 1 dengan bobot sebesar $14.00 \mathrm{~g}$ (Tabel 6).

\section{Bobot Buah Per Tanaman}

Pada musim 1, bobot buah cabai per tanaman Anies IPB yang ditanam di Boyolali $(872.00 \mathrm{~g})$ memiliki nilai yang lebih tinggi dari varietas Tit Super (317.73) dan Trisula (270.13 g). Rataan bobot buah per tanaman pada musim 
Tabel 5. Nilai rata-rata diameter buah $(\mathrm{mm})$ di tiga lokasi dan dua musim

\begin{tabular}{llllllll}
\hline \multirow{2}{*}{ Genotipe } & \multicolumn{2}{c}{ Bogor } & \multicolumn{2}{c}{ Sumedang } & \multicolumn{2}{c}{ Boyolali } & \multirow{2}{*}{ Rataan } \\
\cline { 2 - 6 } & Musim 1 & Musim 2 & Musim 1 & Musim 2 & Musim 1 & Musim 2 & \\
\hline Anies IPB & $18.50 \mathrm{ab}$ & $14.64 \mathrm{bc}$ & $17.21 \mathrm{bc}$ & $19.06 \mathrm{a}$ & $17.37 \mathrm{a}$ & $16.03 \mathrm{a}$ & $17.14 \mathrm{~b}$ \\
IPB002001 & $17.78 \mathrm{ab}$ & $16.65 \mathrm{ab}$ & $13.05 \mathrm{e}$ & $17.29 \mathrm{a}$ & $11.87 \mathrm{ef}$ & $14.55 \mathrm{ab}$ & $15.20 \mathrm{c}$ \\
IPB002046 & $16.90 \mathrm{~b}$ & $14.20 \mathrm{~cd}$ & $17.60 \mathrm{bc}$ & $13.57 \mathrm{~cd}$ & $9.60 \mathrm{~g}$ & $12.02 \mathrm{~cd}$ & $13.98 \mathrm{~d}$ \\
IPB009003 & $14.21 \mathrm{c}$ & $11.71 \mathrm{e}$ & $13.55 \mathrm{de}$ & $14.00 \mathrm{~cd}$ & $14.83 \mathrm{bc}$ & $10.54 \mathrm{~d}$ & $13.14 \mathrm{de}$ \\
IPB009019 & $18.70 \mathrm{ab}$ & $15.96 \mathrm{abc}$ & $13.32 \mathrm{e}$ & $16.95 \mathrm{ab}$ & $13.23 \mathrm{cde}$ & $14.07 \mathrm{abc}$ & $15.37 \mathrm{c}$ \\
IPB015002 & $14.59 \mathrm{c}$ & $12.12 \mathrm{de}$ & $17.51 \mathrm{bc}$ & $12.11 \mathrm{~d}$ & $10.87 \mathrm{fg}$ & $11.31 \mathrm{~d}$ & $13.08 \mathrm{e}$ \\
IPB015008 & $14.48 \mathrm{c}$ & $15.71 \mathrm{abc}$ & $15.55 \mathrm{~cd}$ & $15.07 \mathrm{bc}$ & $12.27 \mathrm{def}$ & $10.97 \mathrm{~d}$ & $14.01 \mathrm{~d}$ \\
TIT Super & $19.44 \mathrm{a}$ & $17.29 \mathrm{a}$ & $21.60 \mathrm{a}$ & $18.69 \mathrm{a}$ & $16.17 \mathrm{ab}$ & $15.00 \mathrm{ab}$ & $18.03 \mathrm{a}$ \\
Trisula & $18.44 \mathrm{ab}$ & $17.75 \mathrm{a}$ & $18.66 \mathrm{~b}$ & $17.30 \mathrm{a}$ & $14.40 \mathrm{bcd}$ & $13.47 \mathrm{bc}$ & $16.67 \mathrm{~b}$ \\
\hline
\end{tabular}

Keterangan: Angka yang diikuti oleh huruf yang sama pada kolom yang sama tidak berbeda nyata berdasarkan uji BNJ pada taraf $5 \%$

Tabel 6. Nilai bobot buah (g) di tiga lokasi dan dua musim

\begin{tabular}{llllllll}
\hline \multirow{2}{*}{ Genotipe } & \multicolumn{2}{c}{ Bogor } & \multicolumn{2}{c}{ Sumedang } & \multicolumn{2}{c}{ Boyolali } & \multirow{2}{*}{ Rataan } \\
\cline { 2 - 6 } & Musim 1 & Musim 2 & Musim 1 & Musim 2 & Musim 1 & Musim 2 & \\
\hline Anies IPB & $10.51 \mathrm{bcd}$ & $10.31 \mathrm{bc}$ & $10.67 \mathrm{ab}$ & $11.34 \mathrm{a}$ & $14.00 \mathrm{a}$ & $10.47 \mathrm{a}$ & $11.22 \mathrm{a}$ \\
IPB002001 & $13.18 \mathrm{ab}$ & $11.28 \mathrm{ab}$ & $9.07 \mathrm{bc}$ & $9.54 \mathrm{abc}$ & $8.97 \mathrm{~d}$ & $10.20 \mathrm{a}$ & $10.37 \mathrm{a}$ \\
IPB002046 & $12.67 \mathrm{ab}$ & $11.19 \mathrm{ab}$ & $12.77 \mathrm{a}$ & $7.70 \mathrm{~cd}$ & $10.13 \mathrm{bcd}$ & $8.53 \mathrm{ab}$ & $10.50 \mathrm{a}$ \\
IPB009003 & $8.90 \mathrm{~cd}$ & $7.41 \mathrm{~d}$ & $7.03 \mathrm{c}$ & $6.47 \mathrm{~d}$ & $11.80 \mathrm{abc}$ & $6.14 \mathrm{~b}$ & $7.96 \mathrm{~b}$ \\
IPB009019 & $13.79 \mathrm{a}$ & $13.09 \mathrm{a}$ & $7.60 \mathrm{c}$ & $8.40 \mathrm{bcd}$ & $11.93 \mathrm{abc}$ & $8.46 \mathrm{ab}$ & $10.55 \mathrm{a}$ \\
IPB015002 & $8.04 \mathrm{~d}$ & $7.99 \mathrm{~cd}$ & $12.77 \mathrm{a}$ & $6.59 \mathrm{~d}$ & $9.53 \mathrm{~cd}$ & $6.93 \mathrm{~b}$ & $8.64 \mathrm{~b}$ \\
IPB015008 & $8.08 \mathrm{~d}$ & $8.15 \mathrm{~cd}$ & $8.90 \mathrm{bc}$ & $7.61 \mathrm{~cd}$ & $12.47 \mathrm{ab}$ & $6.76 \mathrm{~b}$ & $8.66 \mathrm{~b}$ \\
TIT Super & $11.54 \mathrm{abc}$ & $11.03 \mathrm{ab}$ & $12.80 \mathrm{a}$ & $10.81 \mathrm{ab}$ & $13.87 \mathrm{a}$ & $8.41 \mathrm{ab}$ & $11.41 \mathrm{a}$ \\
Trisula & $12.50 \mathrm{ab}$ & $12.57 \mathrm{ab}$ & $12.53 \mathrm{a}$ & $9.31 \mathrm{abc}$ & $12.53 \mathrm{ab}$ & $8.50 \mathrm{ab}$ & $11.32 \mathrm{a}$ \\
\hline
\end{tabular}

Keterangan: Angka yang diikuti oleh huruf yang sama pada kolom yang sama tidak berbeda nyata berdasarkan uji BNJ pada taraf 5\%

1 di tiga lokasi menunjukkan bahwa Anies IPB (545.77 g) memiliki nilai yang lebih tinggi dari varietas Tit Super (375.31 g) dan Trisula (270.13 g). Pada musim 2 bobot buah per tanaman Anies IPB di tiga lokasi penanaman pada dua musim menunjukkan bahwa nilai yang tidak berbeda nyata dengan varietas pembanding. Data tersebut menunjukkan bahwa Anies IPB yang ditanam di daerah Boyolali pada bulan Januari-Juni memiliki produktivitas yang lebih tinggi dibandingkan dengan yang lainnya (Tabel 7). Jika jarak tanam $50 \mathrm{~cm}$ x $50 \mathrm{~cm}$ dengan lebar bedengan $1 \mathrm{~m}$ maka jumlah populasi tanaman per hektar lebih kurang 26670 tanaman (Berke dan Gniffke, 2006). Dengan asumsi bahwa hanya $80 \%$ tanaman yang dapat berproduksi dengan baik maka Anies IPB mempunyai produktivitas 10 ton ha ${ }^{-1}$ dan mempunyai potensi 18.6 ton $\mathrm{ha}^{-1}$.

\section{Analisis Stabilitas}

Beberapa metode untuk menjelaskan dan menginterpretasikan tanggap genotipe terhadap variasi lingkungan telah banyak dikembangkan (Akcura et al., 2006; Yasmin, 2007; Fikere et al., 2009; Rahadi et al., 2013). Salah satu metode yang dapat digunakan adalah metode additive main effect multiplicative interaction (AMMI), seperti yang dilakukan oleh Sujiprihati et al. (2006) dan Syukur et al. (2010. Analisis dengan metode tersebut menggabungkan pengaruh aditif pada analisis ragam dan pengaruh multiplikatif pada analisis komponen utama (Mattjik, 2005).

Pada Gambar 3 biplot antara komponen utama 1 dan komponen utama 2 dapat menjelaskan genotipe-genotipe mana saja yang stabil pada seluruh lokasi uji atau spesifik pada lokasi tertentu. Mattjik dan Sumertajaya (2006) menyatakan bahwa suatu genotipe dikatakan stabil apabila berada dekat dengan sumbu atau titik (0.0). Galur yang berada jauh dari sumbu tetapi berdekatan dengan garis lokasi, maka genotipe tersebut tergolong genotipe-genotipe yang spesifik lokasi. Gambar 3 menunjukkan bahwa genotipe yang stabil di setiap lokasi adalah Anies IPB karena berada dekat dengan titik (0.0). 
Tabel 7. Nilai bobot buah per tanaman (g) di tiga lokasi dan dua musim

\begin{tabular}{llllllll}
\hline \multirow{2}{*}{ Genotipe } & \multicolumn{2}{c}{ Bogor } & \multicolumn{2}{c}{ Sumedang } & \multicolumn{2}{c}{ Boyolali } & \multirow{2}{*}{ Rataan } \\
\cline { 2 - 6 } & Musim 1 & Musim 2 & Musim 1 & Musim 2 & Musim 1 & Musim 2 & \\
\hline Anies IPB & $588.85 \mathrm{a}$ & $742.15 \mathrm{ab}$ & $176.45 \mathrm{a}$ & $180.41 \mathrm{a}$ & $872.00 \mathrm{a}$ & $273.93 \mathrm{a}$ & $472.30 \mathrm{a}$ \\
IPB002001 & $402.98 \mathrm{a}$ & $732.36 \mathrm{ab}$ & $385.26 \mathrm{a}$ & $114.90 \mathrm{a}$ & $478.17 \mathrm{bc}$ & $238.92 \mathrm{a}$ & $392.10 \mathrm{ab}$ \\
IPB002046 & $450.86 \mathrm{a}$ & $813.50 \mathrm{ab}$ & $420.74 \mathrm{a}$ & $66.63 \mathrm{a}$ & $484.60 \mathrm{bc}$ & $319.11 \mathrm{a}$ & $425.91 \mathrm{ab}$ \\
IPB009003 & $460.88 \mathrm{a}$ & $632.01 \mathrm{ab}$ & $288.99 \mathrm{a}$ & $145.41 \mathrm{a}$ & $722.50 \mathrm{ab}$ & $349.33 \mathrm{a}$ & $433.19 \mathrm{ab}$ \\
IPB009019 & $527.21 \mathrm{a}$ & $848.24 \mathrm{a}$ & $174.02 \mathrm{a}$ & $85.60 \mathrm{a}$ & $306.87 \mathrm{c}$ & $241.83 \mathrm{a}$ & $363.96 \mathrm{~b}$ \\
IPB015002 & $435.28 \mathrm{a}$ & $580.54 \mathrm{~b}$ & $251.08 \mathrm{a}$ & $118.27 \mathrm{a}$ & $405.50 \mathrm{c}$ & $276.17 \mathrm{a}$ & $344.47 \mathrm{~b}$ \\
IPB015008 & $631.97 \mathrm{a}$ & $630.53 \mathrm{ab}$ & $328.03 \mathrm{a}$ & $124.24 \mathrm{a}$ & $418.23 \mathrm{c}$ & $257.50 \mathrm{a}$ & $398.42 \mathrm{ab}$ \\
TIT Super & $508.19 \mathrm{a}$ & $648.00 \mathrm{ab}$ & $300.01 \mathrm{a}$ & $100.44 \mathrm{a}$ & $317.73 \mathrm{c}$ & $276.33 \mathrm{a}$ & $358.45 \mathrm{~b}$ \\
Trisula & $502.96 \mathrm{a}$ & $813.37 \mathrm{ab}$ & $316.41 \mathrm{a}$ & $119.84 \mathrm{a}$ & $270.13 \mathrm{c}$ & $291.00 \mathrm{a}$ & $385.62 \mathrm{ab}$ \\
\hline
\end{tabular}

Keterangan: Angka yang diikuti oleh huruf yang sama pada kolom yang sama tidak berbeda nyata berdasarkan uji BNJ pada taraf 5\%

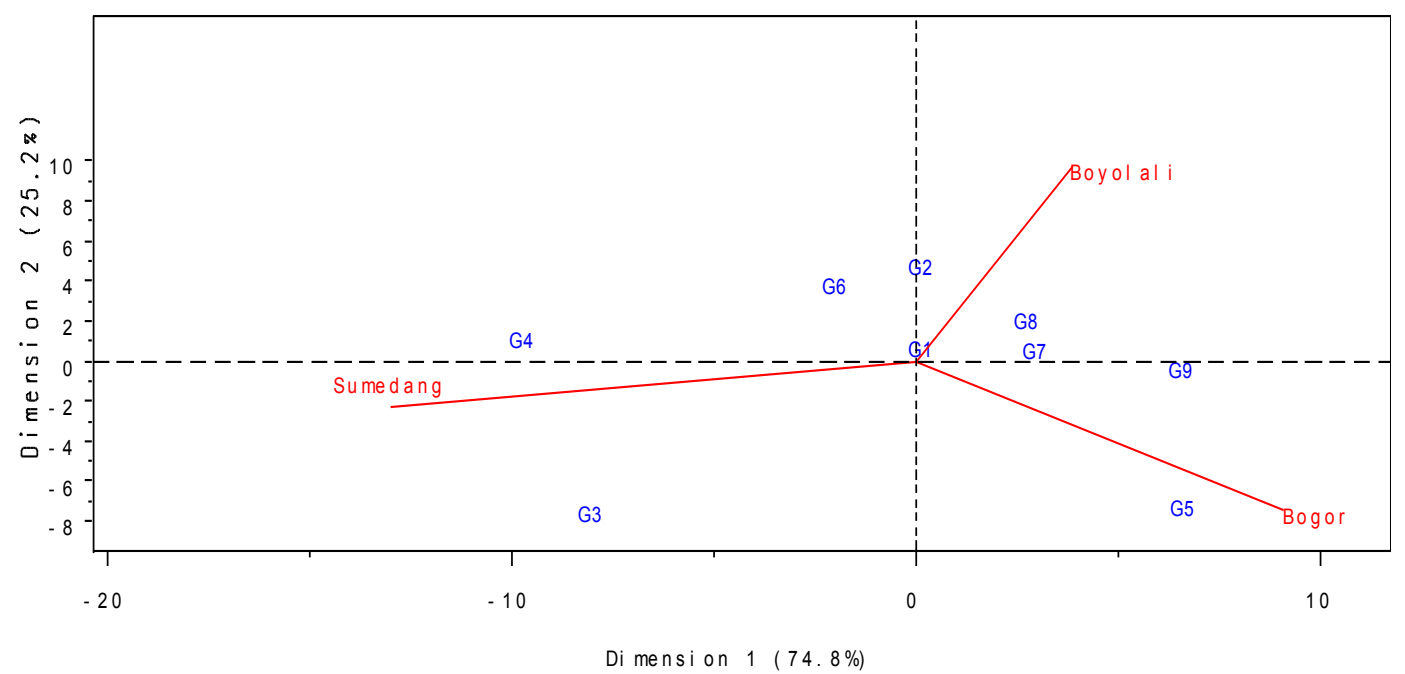

Gambar 2. Biplot Genotipe dan Lingkungan. Anies IPB (G1), IPB002001 (G2), IPB002046 (G3), IPB009003 (G4), IPB009019 (G5), IPB015002 (G6), IPB015008 (G7), Tit Super (G8), dan Trisula (G9)

\section{Keunggulan Calon Varietas}

Keunggulan varietas Anies IPB adalah

1. Produktivitas Anies IPB lebih tinggi dibandingkan dengan varietas pembanding. Produktivitasnya dapat mencapai 18.6 ton $\mathrm{ha}^{-1}$.

2. Anies IPB mempunyai buah yang lebih panjang dari pada
Tit Super dan Trisula.

3. Anies IPB memiliki umur panen yang genjah yaitu berkisar antara $76.67-84.67$ hari setelah tanam.

4. Anies IPB mempunyai tingkat stabilitas tinggi dan digolongkan ke dalam stabilitas dinamis, artinya sangat adaptif terhadap lingkungan optimum.

Tabel 8. Deskripsi Varietas Anies IPB

\begin{tabular}{ll}
\hline Nomor SK & $:$ 008/Kpts/SR.120/D.2.7/2/2015 \\
\hline Asal & $:$ dalam negeri \\
Silsilah & seleksi bulk dimodifikasi hasil persilangan (IPB C120) x (IPB C5) \\
Golongan varietas & $:$ bersari bebas \\
Bentuk tajuk & $:$ Postrate \\
Lebar tajuk & $: 60.07-96.96 \mathrm{~cm}$ \\
Tinggi tanaman & $: 44.20-68.27 \mathrm{~cm}$ \\
\hline
\end{tabular}


Comm. Hort. J, Februari 2017, 1(1):56-64

Lanjutan Tabel 8. Deskripsi Varietas Anies IPB

\begin{tabular}{|c|c|}
\hline Tinggi dikotomus & $: 17.23-21.16 \mathrm{~cm}$ \\
\hline Bentuk penampang batang & : bulat \\
\hline Diameter batang & $: 0.098-0.124 \mathrm{~cm}$ \\
\hline Warna batang & : $\operatorname{hijau}(2.5 \mathrm{G} 7 / 10)$ \\
\hline Warna daun & : hijau tua $(2.5 \mathrm{G} 3 / 5)$ \\
\hline Bentuk daun & : lanceolat \\
\hline Ukuran daun & : panjang $7.61-12.27 \mathrm{~cm}$; lebar $3.18-3.82 \mathrm{~cm}$ \\
\hline Bentuk bunga & : intermediate \\
\hline Posisi bunga & : drooping \\
\hline Posisi stigma & : di bawah benangsari \\
\hline Warna kelopak bunga & : hijau (5 GY 7/10) \\
\hline Warna mahkota bunga & : $\operatorname{putih}(\mathrm{N} 9.5)$ \\
\hline Warna kepala putik & : $\quad$ putih $(\mathrm{N} 9.5)$ \\
\hline Warna benangsari & : $a b u-a b u(N 8)$ \\
\hline Umur mulai berbunga & : $26-32$ hari setelah tanam \\
\hline Umur mulai panen & : $77-85$ hari setelah tanam \\
\hline Bentuk buah & : lurus memanjang \\
\hline Posisi buah & : drooping \\
\hline Bentuk penampang buah & : circular \\
\hline Tekstur permukaan buah & : halus mengkilap \\
\hline Bentuk ujung buah & : cukup meruncing \\
\hline Jumlah rongga buah & : dominan dua \\
\hline Ukuran buah & : panjang $12.02-19.35 \mathrm{~cm}$; diameter $0,15-0,19 \mathrm{~cm}$ \\
\hline Warna buah muda & : hijau medium $(2.5$ G 5/10) \\
\hline Warna buah tua & : merah medium (6 R 5/11.5) \\
\hline Tebal kulit buah & $: \quad 1.93-2.54 \mathrm{~mm}$ \\
\hline Rasa buah & : pedas \\
\hline Bentuk biji & : pipih \\
\hline Warna biji & : kuning jerami \\
\hline Berat 1.000 biji & $: \quad 3.7-4.0 \mathrm{~g}$ \\
\hline Kadar capcaisin & : $368,78 \mathrm{ppm}$ \\
\hline Berat per buah & : $10.31-14.00 \mathrm{~g}$ \\
\hline Jumlah buah per tanaman & : $44-74$ buah \\
\hline Berat buah per tanaman & : $176.45-872.00 \mathrm{~g}$ \\
\hline $\begin{array}{l}\text { Daya simpan buah pada suhu } \\
\text { ruang }\left(25-27^{\circ} \mathrm{C}\right)\end{array}$ & : $8-10$ hari setelah panen \\
\hline Hasil buah per hektar & : $4.23-20.90$ ton \\
\hline Populasi per hektar & $: \pm 25,000$ tanaman \\
\hline Kebutuhan benih per hektar & : $200-300 \mathrm{~g}$ \\
\hline Penciri utama & $\begin{array}{l}\text { permukaan buah sedikit berkerut, ujung buah sedikit melengkung, warna buah } \\
\text { intermediate keunguan, posisi stigma di bawah benangsari }\end{array}$ \\
\hline Keunggulan varietas & : potensi produksi tinggi, umur panen genjah, tingkat stabilitas tinggi \\
\hline Wilayah adaptasi & : beradaptasi dengan baik di dataran rendah dengan ketinggian $104-370 \mathrm{~m}$ dpl \\
\hline Pemohon & : Pusat Kajian Hortikultura Tropika IPB \\
\hline Pemulia & : M. Syukur, Sobir, Siti Marwiyah, Awang Maharijaya \\
\hline Peneliti & $\begin{array}{l}\text { Anas D. Susila, Darda Efendi, Widodo, Sri Hendrastuti Hidayat, Vitria P. Rahadi, } \\
\text { Abdul Hakim, Tiara Yudilastari, Arya Widura Ritonga, Ilham Framansyah }\end{array}$ \\
\hline
\end{tabular}




\section{DESKRIPSI VARIETAS ANIES IPB}

Varietas Anies IPB mendapatkan terdaftar di Kementerian Pertanian sejak tahun 2015 berdasarkan SK No. 008/Kpts/SR.120/D.2.7/2/2015. Deskripsi varietas Anies IPB ditampilkan pada Tabel 8.

\section{UCAPAN TERIMA KASIH}

Terima kasih disampaikan kepada kementerian Ristekdikti melalui berbagai penelitian sejak tahun 2008 sampai tahun 2015 .

\section{DAFTAR PUSTAKA}

Akcura, M., Y. Kaya, S. Taner, R. Ayranci. 2006. Parametric stability analyses for grain yield of durum wheat. Plant Soil Environ. 6:254-261.

Badan Standardisasi Nasional. 1998. Standar Nasional Indonesia Cabai Merah Segar, SNI No. 01-4481998.

Bank Indonesia. 2016. Release Note Inflasi Oktober 2016. http://www.bi.go.id/id/moneter/koordinasipengendalian-inflasi/. Diakses pada 22 Desember 2016.

Berke, T.G., P. Gniffke. 2006. Procedures for sweet pepper field evaluation trials. AVRDC, Taiwan.

Direktorat Jenderal Hortikultura. 2016. Produksi, Luas Panen, dan Produktivitas Sayuran di Indonesia. http:// www.pertanian.go.id/Indikator/tabel-2-prod-lspnprodvitas-horti.pdf. Diakses 25 September 2016.

Fikere, M., E. Fikiru, T. Tadesse, T. Legesse. 2009. Parametric stability analyses in fi eld pea (Pisum sativum L.) under South Eastern Ethiopian condition. World J. Agric. Sci. 5:146-151.
Hartuti, N., A. Asgar. 1992. Kualitas bahan baku dan hasil olahan cabai di tingkat industri komersial dan rumah tangga di Bandung. Bul. Penel. Hort. 26:142-150.

Mattjik, A.A. 2005. Interaksi genotipe dan lingkungan dalam penyediaan sumberdaya unggul. [Orasi Ilmiah Guru Besar tetap Biometrika]. Institut Pertanian Bogor, Bogor.

Mattjik, A.A., I.M. Sumertajaya. 2006. Perancangan Percobaan dengan Aplikasi SAS dan Minitab. Edisi ke-2. IPB Press, Bogor.

Rahadi, V.P., M. Syukur, S. Sujiprihati and R. Yunianti. 2013. Nonparametric stability analysis of yield for nine chili pepper (Capsicum annuum L.) genotypes in eight environments. Agrivita 35(2): 193-200.

Sayaka, B., I.W. Yusastra, R. Sajuti, Supriyati, W.K. Sejati, A. Agustian, Y. Supriyatna, I.S. Anugrah, R. Elizabeth, Ashari, J. Situmorang. 2008. Pengembangan kelembagaan partnership dalam pemasaran komoditas pertanian. Ringkasan Eksekutif Laporan Akhir Penelitian. Pusat Analisis Sosial Ekonomi dan Kebijakan Pertanian, Departemen Pertanian.

Sujiprihati, S., M. Syukur, R. Yunianti. 2006b. Analisis stabilitas hasil tujuh populasi manis menggunakan metode Additive Main Effect Multiplicative Interaction (AMMI). Bul. Agron. 34:93-97.

Syukur, M., S. Sujiprihati dan R. Yunianti. 2015. Teknik Pemuliaan Tanaman. Edisi Revisi. Penebar Swadaya. Bogor.

Syukur, M., S. Sujiprihati, R. Yunianti, D.A. Kusumah. 2010. Evaluasi daya hasil cabai hibrida dan daya adaptasinya di empat lokasi dalam dua tahun. J. Agron. Indonesia 38(1):43 - 51 .

Yasmin, S. 2007. Evaluation of promising wheat genotypes by the stability analysis through parametric and nonparametric methods. Int. J. Sustain. Crop Prod. 2:9-16. 